have recognized, but science had replaced faith as the redeeming agent. Science would direct the American people "in a legitimate course of development".

The most famous aspect of Powell's education of the American people was his attempt to make American settlement conform to what he regarded as the logic of the arid West, where scarce water limited both the extent and form of settlement. There were really two attempts at this - his "Report on the Arid Lands of the United States" in 1878, and what began as a partnership with Senator William Stewart of Nevada to irrigate the West in 1890. Both failed, and their failure forms the central story of Worster's book.

Worster has two standards for measuring Powell the reformer: respect for nature and the struggle for social justice. Powell's record is mixed on both, and the gap between Powell's actions and Worster's standards creates a productive tension in the book. But this is not a case of an author imposing modern standards on the past; rather, nineteenthcentury concerns resonate with modern concerns in an interesting and revealing way. Powell's "Report on the Arid Lands of the United States" was, according to Worster, trapped in fundamental contradictions. It identified a natural pattern that Powell wanted to use as the basis for a social pattern. "Nature in the West had drawn the lines that law, politics, land and water use, and economic development must obey." Powell paid tribute to nature only in order to transform it. The survey was a search for the best site for dams that would plug every rivulet in the West and allow no drop to go to waste. It served a populist agrarianism that has Worster's sympathies, but it was still an assault on nature. For Worster, who believes deeply that nature provides patterns that humans should follow, it was the Achilles heel of a flawed, important and truly revealing figure.

Richard White is in the Department of History, Stanford University, Stanford, California 94305-2024, USA.

\section{Taxonomy and the blues}

\section{Nabokov's Blues: The Scientific Odyssey of a Literary Genius by Kurt Johnson \& Steve Coates Zoland Books: 2000. 372 pp. £18.99, \$27}

\section{James Mallet}

Vladimir Nabokov the towering man of letters was also the geeky and shambling lepidopterist who, every summer, roamed the uplands of North America or Europe with a butterfly net. Lolita (1958) and other novels were actually written while he was on butter-

fly-collecting trips in the Rockies. Nabokov won international fame as a novelist and poet after Lolita, but he was even more proud that a handful of specialists had named butterflies after him. In spite of its subtitle, The Scientific Odyssey of a Literary Genius, Nabokov's Blues is not primarily another biographical work about the great writer. The many references to butterflies in Nabokov's novels and poems, and his taxonomic work on the 'blues' (Lycaenidae), are discussed at length, but the odyssey in the subtitle properly belongs to author Kurt Johnson, a New York financier and lepidopterist. The real hero of Nabokov's Blues is taxonomy; its supporting cast, in addition to Nabokov and Johnson, includes Hungarian $\mathrm{PhD}$ student Zsolt Bálint, Israeli engineer Dubi Benyamini and Peruvian entomologist Gerardo Lamas.

Nabokov's Blues thoroughly captures the joys and frustrations of taxonomic discovery. With Johnson and Steve Coates, a New York Times journalist, the reader battles through mudslides and guerrilla roadblocks to remote sites in the Andes and Caribbean, dissects butterfly genitalia under a microscope, visits isolated European museums in search of dusty and forgotten type specimens, peruses the literature, vindicates Nabokov's pioneering taxonomy, and finally races to describe and publish new discoveries ahead of competitors. This may be the first book to exploit

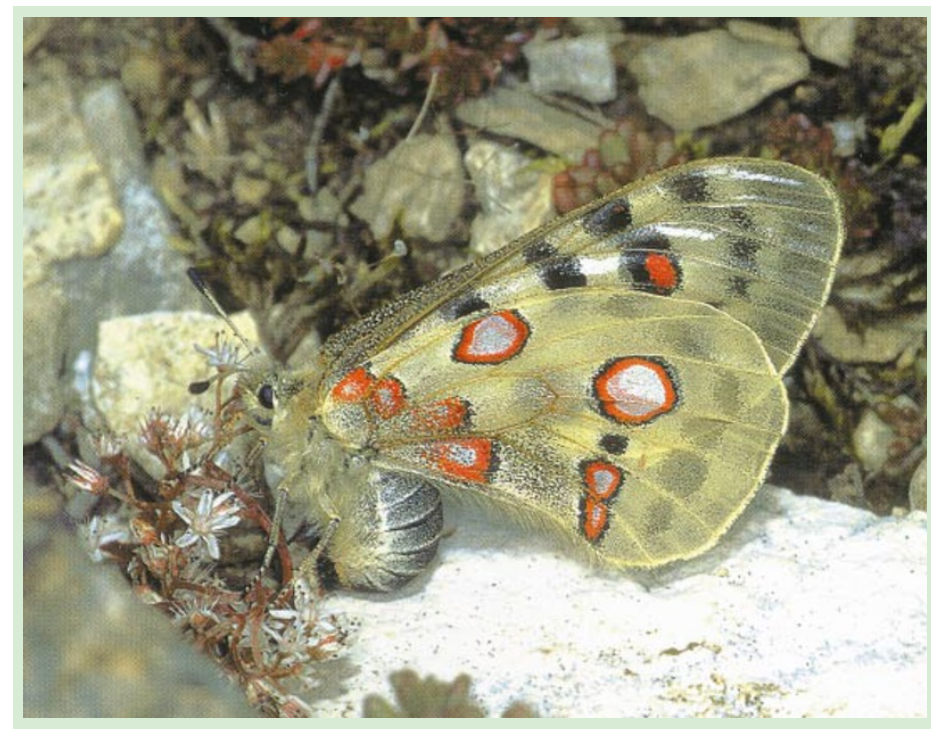

\title{
Wings and other things
}

Phil Schappert, the author of $A$ World for Butterflies: Their Lives, Behavior and Future (Firefly, \$35), calls them "the charismatic megafauna" of the insect world. His lavishly illustrated book provides an introduction to this ephemeral but ubiquitous arthropod, together with the reasons that many species have become endangered. Further intimate portraits of these and other insects are

alpha-taxonomy for its thrill value. It is a most unlikely bestseller, but the book succeeds by romping enthusiastically around the arcane world of butterflies and butterfly taxonomists.

Most of us know about the extinction crisis in biological diversity. Less publicized is the fact that we can't even estimate the scale of this global disaster because of a crisis in taxonomy itself: we haven't a clue how many species there are, even to an order of magnitude (estimates vary between 1 and 100 million). I can download onto this very computer information on stars billions of light years away, find detailed information about every square metre of the Earth from among terabytes of online satellite data, and identify each of the $10^{8}$ base pairs of DNA in the genome of the tiny fly buzzing round my glass of claret. But there is no universal taxonomic database. In spite of its fundamental importance in biology, taxonomy is today at one of its lowest ebbs, and only survives through the fevered activity of a few poorly paid but dedicated museum curators, as well as a Dad's Army of retirees, amateurs and volunteers. Nabokov's Blues provides a much-needed portrayal of this close-knit yet scattered international community.

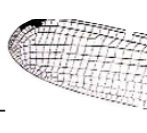
Although he personally Although hescribed personally

to be found in The Hand of Nature: Butterflies, Beetles and Dragonflies (Thames \&

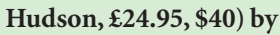
Jacques Kerchache and Ettore Sottsass Jr, with photography by Patrick Gries. The book is a photographic record of Kerchache's insect collection. 


\section{book reviews}

many new species of 'hairstreak' butterflies (like Nabokov's blues, also Lycaenidae), Johnson himself is far from respected as a taxonomist. Even Johnson's unpaid associate status at the American Museum of Natural History was terminated in 1996 . In an e-mail, Johnson himself now admits to " $10-20 \%$ or less errors" in his earlier taxonomic work although others put his synonymy rate higher (the criticisms do not apply to his recent collaboration with Zsolt Bálint). For a taxonomist, it seems extraordinarily careless that Johnson refers in Nabokov's Blues to species "epitaphs", when he means "epithets" (names). Such errors are unacceptable to taxonomists, who take pride in their accuracy and orthography. Nonetheless, in his new metamorphosis as bestselling author, Johnson keeps any bitterness he may feel towards critics out of this lively book - hints that he is a renegade only add to the charm. Instead, Johnson and Coates advertise a much more valuable and convincing message: taxonomy is fun!

James Mallet is in the Department of Biology, Galton Laboratory, University College London, 4 Stephenson Way, London NW1 2HE, UK.

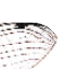

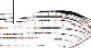

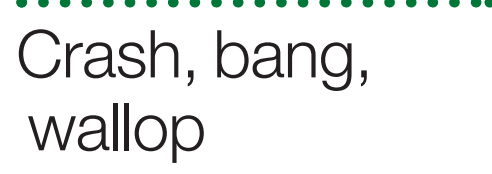

Science of Percussion Instruments by Thomas D. Rossing

World Scientific Publishing: 2000. 208 pp.

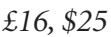

\section{Bernard Richardson}

Have you noticed a strange new phenomenon at concert halls? Percussionists, who used to stand at the back of the orchestra tapping out the rhythm or punctuating the odd climax with a cymbal crash, are increasingly taking centre stage. Armed with a vast array of instruments, they treat the audience to virtuosic performances which seem to rely as much on athletic prowess as musicianship. If you have difficulty in putting a name to half of these instruments, or have ever wondered why and how they produce such a wide range of musical sounds, then this authoritative book by an expert will be a welcome addition to your bookshelves.

Percussion instruments are a little different from the other regular members of the orchestra. Strings, woodwind and brass combine some type of oscillator (string or reed) with a resonator (a wooden box or air column) in such a way as to produce sustained sounds with strictly harmonic overtones. This is why we perceive these instruments as having a very definite pitch and why their sounds can be combined so harmoniously. In contrast, percussion instruments

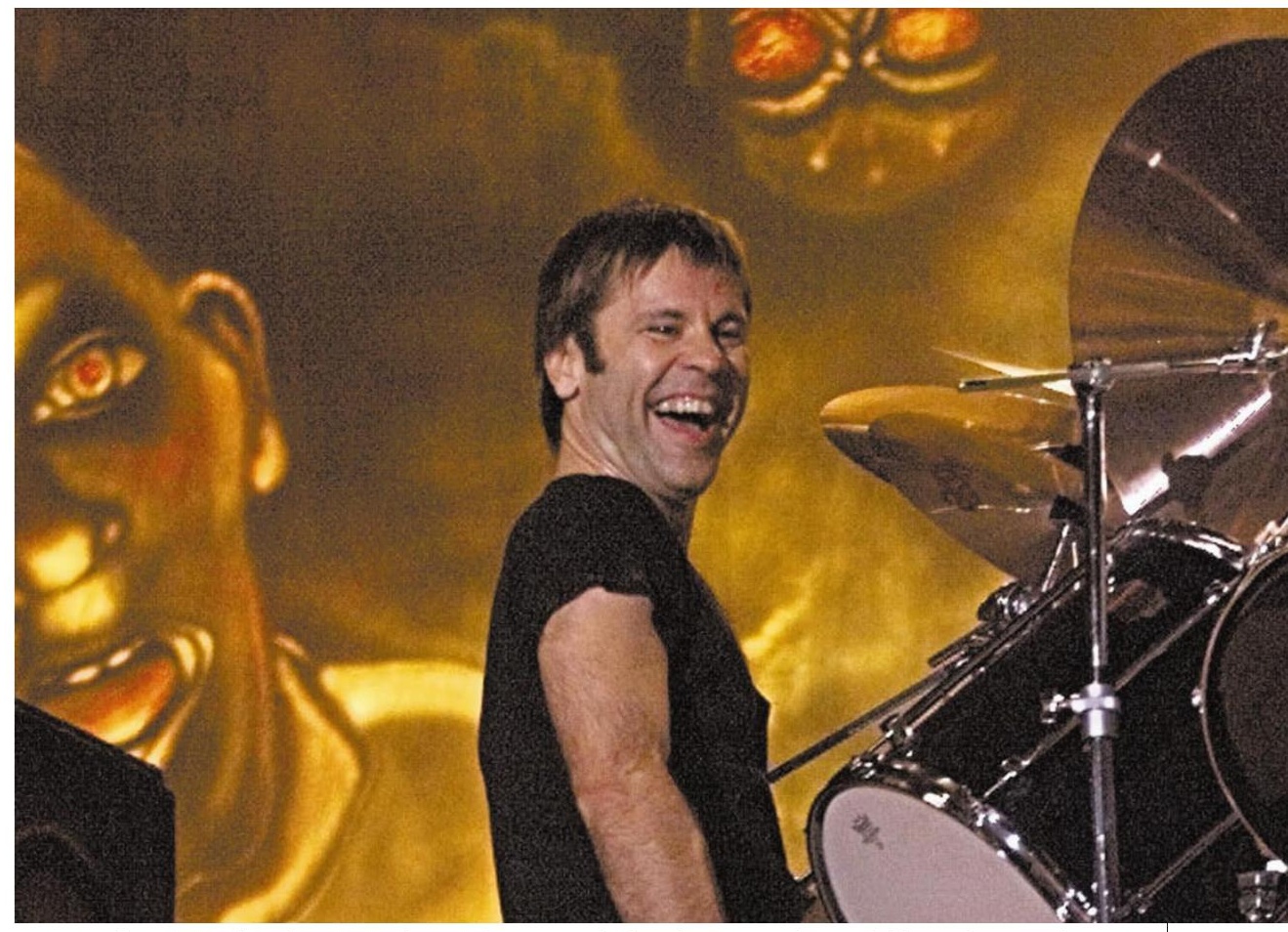

Beating all comers: there's more to drums than even the band Iron Maiden could have dreamt of.

combine the oscillator and resonator in one, producing sounds through the transient excitation of the natural vibrations of bars, plates, stretched membranes and shells made from a host of different materials. The ensuing vibrations of these structures tend to produce short-lived sounds comprising inharmonic overtones. It is this rather haphazard overtone structure, and the way it develops with time, which determines the sound quality of each instrument. The key to understanding the acoustics of percussion instruments is thus to study the modes of vibration of the different groups of instruments - and that is largely what this book is about.

Thomas D. Rossing has written this book for a general readership and therefore assumes no particular scientific background. Rossing is professor of physics at Northern Illinois University in DeKalb, and has been actively involved in musical acoustics for more than 30 years. Much of his own work has concentrated on the acoustics of percussion instruments, and he has also been active in promoting science through his work for the Acoustical Society of America and the American Association for the Advancement of Science (of which he is an ex-president).

In the book, so that they can be visited at any time, bits of physics or descriptions of specialized techniques (such as the holographic interferometry used to visualize vibrations) are presented in "interludes". Whether or not these interludes contain sufficient background material to explain essential concepts to musicians and instrument-makers is debatable. However, the book is certainly accessible to scientists interested in music, although I would have liked to have seen a little more on psychoacoustics, the science of measuring or explaining how we hear. A section on materials and damping, and a more fundamental approach to sound radiation would also have been welcome. Like other books on musical acoustics, this one is organized logically with sections on each of the major families of instruments (making it useful as a reference text).

What singles this book out is the sheer diversity of instruments covered. There are gamelans and gongs, bongos and bodhráns, tam-tams, thunder sheets and typewriters if it makes a noise when you hit it, you will probably find it in this book. There is inevitable overlap with material from one of Rossing's previous books, The Physics of Musical Instruments (co-authored by Neville Fletcher; Springer, 1991), but there is sufficient new scientific material and a wealth of interesting snippets about the origins, use and manufacture of instruments to warrant this new publication.

A good third of the book is, quite reasonably, devoted to bells and Caribbean steel drums. These are part of a special class of 'tuned' percussion that demonstrates how, in the hands of skilled instrument-makers, the modes of vibration can be brought into near-exact harmonic alignment, giving them a precise pitch. Bell tuning is an example of a lost art rediscovered in the late nineteenth century, partly as a result of the monumental acoustical work of Lord Rayleigh. Modern bell tuning is done electronically on a large vertical lathe, gradually 